\title{
Correction: Aberrant iPSC-derived human astrocytes in Alzheimer's disease
}

\author{
V. C. Jones ${ }^{1}$, R. Atkinson-Dell ${ }^{2}$, A. Verkhratsky ${ }^{2,3}$ and L. Mohamet $^{2}$
}

\section{Correction to: Cell Death \& Disease 8:e2696 https://doi.org/10.1038/cddis.2017.89 published online 23 March 2017}

The original version of this Article contained an error in Fig. 1, in which a number of incorrect fluorescence images were inadvertently incorporated into the panel. The conclusions of the paper are not changed in any way by this correction, and the authors apologize for the inconvenience.

The correct version of Fig. 1 is:

This has been corrected in both the PDF and HTML versions of the Article.

Published online: 12 March 2019

Correspondence: L. Mohamet (lisa.mohamet@manchester.ac.uk)

${ }^{1}$ The University of Central Lancashire, Preston PR1 2HE, UK

${ }^{2}$ The University of Manchester, Manchester M13 9PT, UK

${ }^{3}$ Achucarro Center for Neuroscience, IKERBASQUE, Basque Foundation for

Science, Bilbao 48011, Spain

\section{(c) The Author(s) 2019}

(c) (i) Open Access This article is licensed under a Creative Commons Attribution 4.0 International License, which permits use, sharing, adaptation, distribution and reproduction cc) in any medium or format, as long as you give appropriate credit to the original author(s) and the source, provide a link to the Creative Commons license, and indicate if changes were made. The images or other third party material in this article are included in the article's Creative Commons license, unless indicated otherwise in a credit line to the material. If material is not included in the article's Creative Commons license and your intended use is not permitted by statutory regulation or exceeds the permitted use, you will need to obtain permission directly from the copyright holder. To view a copy of this license, visit http://creativecommons.org/licenses/by/4.0/. 


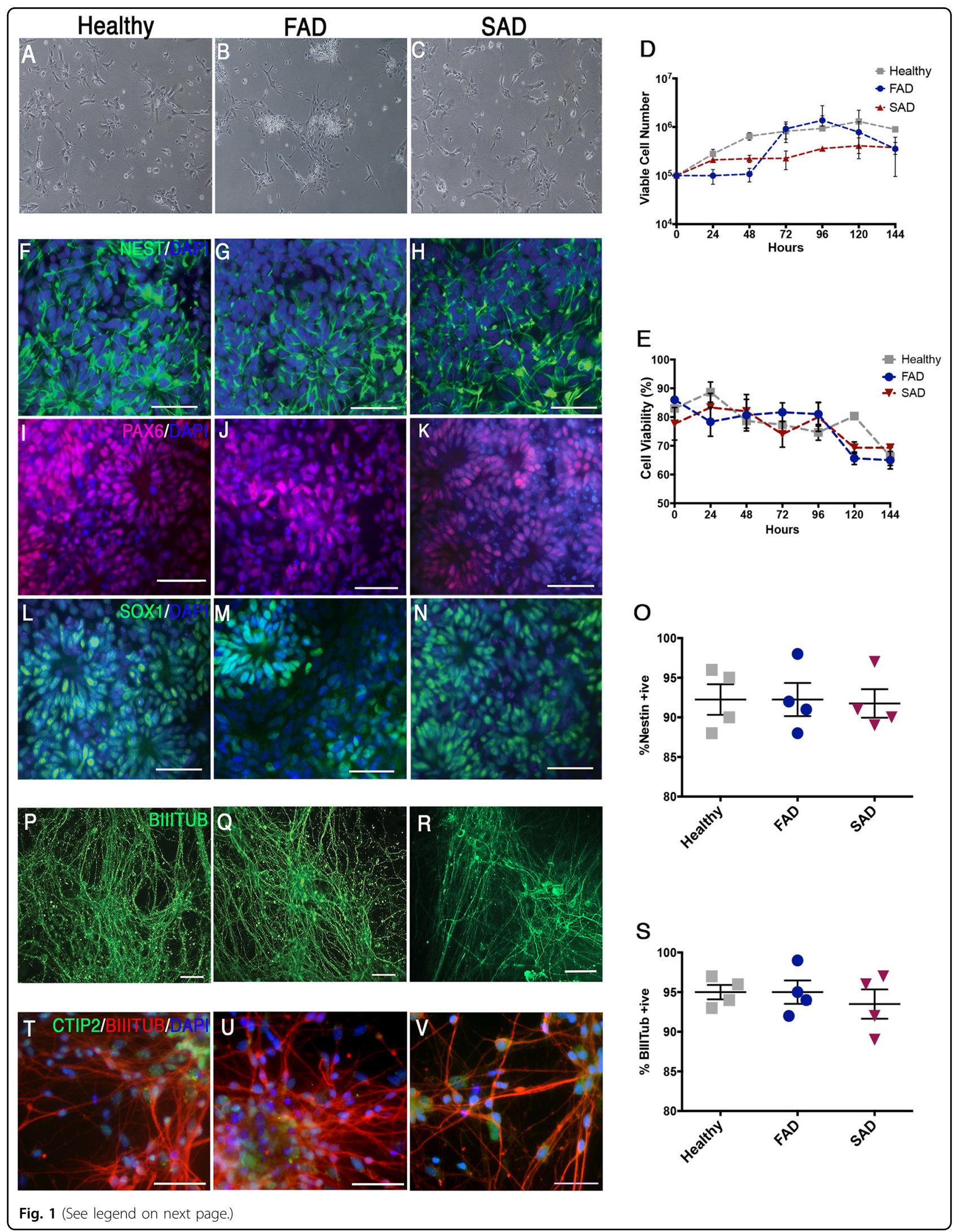


(see figure on previous page)

Fig. 1 Directed differentiation of healthy and AD-neural progenitor cells into cortical neurones. a-c NPCs were seeded at $1 \times 10^{5}$ per well and propagated in monolayer culture for 6/7 days. FAD and SAD cortical NPCs showed indistinguishable culture morphology with healthy (control) NPCs ( $N=5$ per cell line). $\mathbf{d}$ and e No significant differences in NPC growth rates were identified ( $N=4$ per cell line, two-way Kruskal-Wallis $P=N S)$. $\mathbf{f}-\mathbf{n}$ IPS-derived NPCs from healthy (control), FAD and SAD patients were assessed for canonical marker expression. Progenitor cells formed polarised rosettes expressing nestin (green; $\mathbf{f}-\mathbf{h})$, PAX6 (red; i-k) and SOX1 (green, $\mathbf{I}-\mathbf{n})$. o No significant difference in nestin+ cells was observed between healthy and AD cell lines ( $N=4$ per cell line, ANOVA, $\left.F_{(2,9)}=0.022, P=N S\right)$. $\mathbf{p}-\mathbf{r}$ Under terminal neuronal differentiation conditions for 35-40 days, all patient samples showed positive expression of the neural marker $\beta$-III-tubulin (green). $\mathbf{s}$ No significant difference in the proportion of $\beta$-III-tubulin+ neurones between any individual ( $N=4$ per group, ANOVA, $\left.F_{(2,9)}=0.128, P=N S\right)$. $\mathbf{t}-\mathbf{v}$ Expression of the mature deep-layer cortical neuronal marker, CTIP2 was observed throughout cultures from each patient (green). Scale bars, $50 \mu \mathrm{m}$ 